\title{
A Atualização dos Primeiros Métodos de Alfabetização em Propostas Contemporâneas
}

\author{
Iole Maria Faviero Trindade \\ Darlize Teixeira de Mello" \\ Thaise da Silva"I
}

'Universidade Federal do Rio Grande do Sul (UFRGS), Porto Alegre/RS-Brasil

"Universidade Luterana do Brasil (ULBRA), Canoas/RS-Brasil

"'Universidade Federal da Grande Dourados (UFGD), Dourados/MS - Brasil

RESUMO - A Atualização dos Primeiros Métodos de Alfabetização em Propostas Contemporâneas. Este trabalho contextualiza a trajetória dos discursos na área da alfabetização, por meio do exame de seus primeiros métodos com soletração e sem soletração, de ordens discursivas, como a analítica e a sintética, e de propostas de alfabetização veiculadas por políticas públicas, como a do Programa Nacional do Livro Didático e a Provinha Brasil, no que concerne à implementação e avaliação da alfabetização, a partir da implantação do ensino fundamental de nove anos nas escolas brasileiras, desde o ano de 2006. Tal contextualização objetiva localizar a atualização dos primeiros métodos de ensino da leitura e da escrita e suas ordens discursivas em propostas de alfabetização contemporâneas.

Palavras-chave: Métodos Tradicionais de Alfabetização. Propostas Contemporâneas de Alfabetização. Estudos Culturais em Educação. Programa Nacional do Livro Didático. Provinha Brasil.

ABSTRACT - Updating Early Methods of Reading Instruction in Contemporary Proposals. This work contextualizes the path of discourses in the field of reading instruction by examining its early methods with and without spelling, discursive orders such as the analytic and the synthetic one, and proposals of literacy disseminated by public policies such as Programa Nacional do Livro Didático and Provinha Brasil, concerning the implementation and assessment of reading instruction by setting up the nine-year elementary/middle school education from 2006 on. This contextualization aims at situating the updating of early methods of reading and writing teaching and their discursive orders in proposals for contemporary reading instruction. Keywords: Mainstream Literacy Methods. Contemporary Literacy Proposals. Cultural Studies in Education. Programa Nacional do Livro Didático. Provinha Brasil Policy.

Educação \& Realidade, Porto Alegre, v. 40, n. 3, p. 829-857, jul./set. 2015. 829 http://dx.doi.org/10.1590/2175-623641516 


\section{Introdução}

O presente estudo articula os temas principais das três teses de doutorado apresentadas pelas autoras do artigo, no campo mais geral da Alfabetização. A abordagem de tais temas ganha, aqui, novos destaques e recortes de análise, em relação às teses originais.

Da primeira tese (Trindade, 2001; 2004) ${ }^{1}$, que trata de discursos e representações presentes nas cartilhas usadas na alfabetização no estado do Rio Grande do Sul, entre 1890 e 1930, é pinçado o estudo de três cartilhas portuguesas, por considerarmos que elas ilustram o movimento de constituição de um material didático para o ensino da leitura e influíram na produção de contrafações brasileiras, reconhecidas como mais ou menos adequadas. São elas: Cartinha para aprender a ler, de João de Barros (1496-1570), o Método Castilho para o ensino rápido e aprazivel do ler impresso, manuscrito, e numeração e do escrever. Obra tão própria para as escolas como para uso das famílias, de António Feliciano de Castilho (1800-1875) e a Cartilha maternal ou arte da leitura, de João de Deus (1830-1896) ${ }^{2}$.

Da segunda tese (Silva, 2012) ${ }^{3}$, que examina como os discursos na área da alfabetização são representados nos "novos" livros de alfabetização, é destacada a análise do livro didático de alfabetização mais escolhido para uso na rede municipal de ensino de Porto Alegre, a partir do Programa Nacional do Livro Didático - PNLD 2010. É ele: Porta aberta: letramento e alfabetização linguística: $1^{\circ} \mathrm{ano}^{4}$, de Isabella Pessoa de Melo Carpaneda e Angiolina Domanico Bragança (2008). Serão analisadas, ao longo do artigo, quatro das oito atividades presentes na lição da letra " $t$ ", lição escolhida por ser a da primeira consoante apresentada nesse livro. Já as quatro atividades são as que dizem respeito ao eixo alfabetização linguística ${ }^{6}$, destacadas para discussão neste estudo.

Da terceira tese (Mello, 2012) ${ }^{7}$, que analisa a emergência da Provinha Brasil e discute sua finalidade e seus possíveis efeitos enquanto prática externa e interna de avaliação escolar, isto é, suas implicações no gerenciamento de políticas públicas educacionais neoliberais na Rede Municipal de ensino de Porto Alegre, são focalizadas quatro questões das edições de 2008 a 2010/Testes 1 e 2 (Brasil, 2008b; 2009c; 2010). Tais questões pertencem ao eixo apropriação do sistema de escrita ${ }^{8}$, envolvendo, principalmente, os descritores da Provinha Brasil de reconhecimento de letras e de sílabas, assim como a relação grafema-fonema.

Como já foi possível perceber, por meio da apresentação inicial da origem deste estudo, os referenciais teóricos que amparam as análises empreendidas nas teses e nestes novos recortes de análise decorrem do campo dos Estudos Culturais pós-modernos e pós-estruturalistas, conforme as peculiaridades de cada estudo.

Os Estudos Culturais surgem como um movimento teórico e político que se articulou contra uma visão elitista de cultura, marcada 
pelo binarismo alta cultura - o melhor que já se pensou e disse em uma sociedade -, em oposição ao que era considerado como parte da baixa cultura, o saber popular (Hall, 1997). Mattelart (2004, p. 13) descreve o surgimento dos Estudos Culturais associado a uma outra interpretação do conceito de cultura:

Podemos qualificar, portanto, a emergência dos Cultural Studies como a de um paradigma, de um questionamento teórico corrente. Trata-se de considerar a cultura em sentido amplo, antropológico, de passar de uma reflexão centrada sobre o vínculo cultura-nação para uma abordagem da cultura dos grupos sociais. Mesmo que ela permaneça fixada sobre uma dimensão política, a questão central é compreender em que a cultura de um grupo, e inicialmente a das classes populares, funciona como contestação da ordem social ou, contrariamente, como modo de adesão às relações de poder.

Os Estudos Culturais se aproximam do pós-modernismo nas suas similaridades de compreensão das instabilidades do mundo contemporâneo, da desintegração das metanarrativas, da ruptura com a ordem estabelecida, da conexão planetária viabilizada pelos meios de comunicação, das questões que envolvem as migrações e desterritorializações (Costa; Silveira; Sommer, 2003) e se aproximam do pós-estruturalismo nas questões referentes à linguagem e ao poder constituidor dos discursos (Barker; Galasinski, 2001). Cabe a vertente pós-estruturalista de tal campo de conhecimento dar centralidade à linguagem, mostrando o quanto sua produção é fluida e incerta, desmistificando, dessa forma, as verdades científicas, vendo-as como parciais e provisórias. Dessa forma, conhecer e representar são vistos como processos inseparáveis. Ou seja:

[...] o que dizemos sobre as coisas nem são as próprias coisas (como imagina o pensamento mágico), nem são uma representação das coisas (como imagina o pensamento moderno): ao falarmos sobre as coisas nós as constituímos. Em outras palavras: os enunciados fazem mais do que uma representação do mundo; eles produzem o mundo (Veiga-Neto, 1996, p. 28).

Tais campos de estudos permitem-nos lançar um olhar de estranhamento sobre os estudos da área da alfabetização. Nesse sentido, procuramos buscar nos discursos circulantes em coleções do PNLD 2010 e em questões da Provinha Brasil, entre 2008 e 2010, marcas dos discursos presentes em obras didáticas usadas em língua portuguesa produzidas entre os séculos XVI e XIX. Essa busca nos permite ilustrar a permanência do valor dado ao reconhecimento e nomeação das letras e sílabas na formação da palavra escrita. Permite ilustrar, portanto, como a gramática, entendida como a arte de ensinar a ler e a escrever corretamente (Guimarães, 2001) implica o uso das convenções ortográ- 
A Atualização dos Primeiros Métodos de Alfabetização...

ficas, que reaparecem nas atividades dos livros didáticos do PNLD e nas questões da Provinha Brasil. Tal reflexão restringe-se a uma das facetas da alfabetização, como sugere Soares (1996) - a da aquisição ou apropriação do sistema de escrita, que envolve as relações entre o sistema fonológico e os sistemas alfabético e ortográfico.

Além desta introdução, o presente estudo apresenta mais quatro seções.

A seção Da Soletração Antiga e Moderna ao Reconhecimento de Letras, Sílabas e Palavras toma como referência o método de soletração antiga e o apresenta por meio da obra didática portuguesa Cartinha de aprender a ler (Barros, 1539). Dá destaque para a lição que explora a letra inicial por meio da apresentação do alfabeto na sequência convencional existente à época, ilustrado por figuras e pelo nome de cada uma delas. Observe-se que tal destaque pode ser localizado nos materiais didáticos e de avaliação contemporâneos.

A seção Da Análise da Palavra Falada à Palavra Escrita exemplifica o método da não soletração - o qual despreza a ordem tradicional do alfabeto e prioriza a análise da palavra falada - a partir de mais uma obra didática portuguesa, a do Método Castilho (Castilho, 1853). Os mesmos materiais contemporâneos são examinados, agora a partir da segmentação das palavras em sílabas.

Já a seção Do Principio Alfabético ao Principio Ortográfico de Escrita ilustra a não fragmentação da palavra escrita proposta em outro método português, o de João de Deus, por meio da Cartilha maternal (Deus, 1876). Os materiais contemporâneos exploram a produção escrita e/ou a leitura de palavras formadas por sílabas canônicas e não canônicas.

Por fim, a seção Algumas Observações e Provocações Finais, sem ter a pretensão de prescrever condutas pedagógicas, sugere a continuidade da discussão desenvolvida, apontando algumas questões que ficam em aberto.

Vejamos, então, a partir das próximas seções, de forma comparativa, a permanência dos discursos que constituíram as antigas obras didáticas na produção de obras didáticas contemporâneas e na avaliação do desempenho dos alfabetizados. Contamos com os Estudos Culturais, em suas interpretações pós-moderna e pós-estruturalista para realizar tal discussão.

\section{Da Soletração Antiga e Moderna ao Reconhecimento de Letras, Sílabas e Palavras}

A Cartinha para Aprender a Ler, de João de Barros (1539), como primeiro material impresso em Portugal visando ao ensino da leitura, já que antes se ensinava em papéis manuscritos, representaria um método de ensino da leitura que viria a ser reconhecido como soletração 
antiga, quando, mais tarde, as consoantes passassem a ser nomeadas de uma forma que, julgava-se, facilitaria a compreensão da formação da palavra pela criança. Ao discutir uma das possíveis divisões que os métodos de leitura receberiam no século XIX, em Portugal, Lage (1924) apresenta três categorias que, segundo o autor, corresponderiam à maneira de se decomporem os elementos da palavra que se estuda. Tais categorias seriam: método da antiga soletração, método da nova soletração e método sem soletração.

O método da antiga soletração, que poderia ser associado ao da cartinha de João de Barros, consistiria em:

[...] ensinar as vogais e os demais nomes das letras por ordem alfabética, formar sílabas diretas por igual ordem - nomeando separadamente as letras e pronunciando-as, logo em seguida, unidas; da mesma forma se ensinariam as sílabas inversas e as compostas, concluindo com as palavras (Escolano Benito, 1997, p. 231-232).

Já o método da nova soletração, ou soletração moderna, teria um procedimento semelhante ao anterior, só que suprimiria a nomeação das consoantes. Esse método também modificaria a denominação dada às letras ${ }^{9}$. O método sem soletração, assim categorizado por Lage (1924, p. 288), consistiria em “[...] se dispensar a soletração, passando-se logo para o estudo das sílabas"10.

Dando um salto histórico de alguns séculos, comparemos o discurso da soletração, presente na Cartinha para aprender a ler (Barros, 1539), com sua emergência no livro didático Porta aberta (Carpaneda; Bragança, 2008) ${ }^{11}$ e na Provinha Brasil (Brasil, 2008b; 2008c; 2009c; 2010) $)^{12}$.

Em uma das lições da Cartinha para Aprender a Ler (Figura 1), tal discurso se concretiza na presença de uma palavra que, além de vir acompanhada pela imagem do ser que nomeia, com vistas a facilitar a sua leitura, tem destacada, ainda, a letra inicial, respeitando a sequência do alfabeto. Vigoroso entre os séculos XVI e XIX, tal método de ensino da leitura dava destaque à nomenclatura das letras e ao ensino simultâneo de todo o alfabeto, ao apresentar as letras seguindo a ordem alfabética, em sílabas, por uma ordem crescente de complexidade quanto ao número de letras de que são formadas; apenas posteriormente se formavam palavras (Lage, 1924) ${ }^{13}$. 
Figura 1 - Primeira parte do alfabeto da Cartinha para aprender a ler $^{14}$

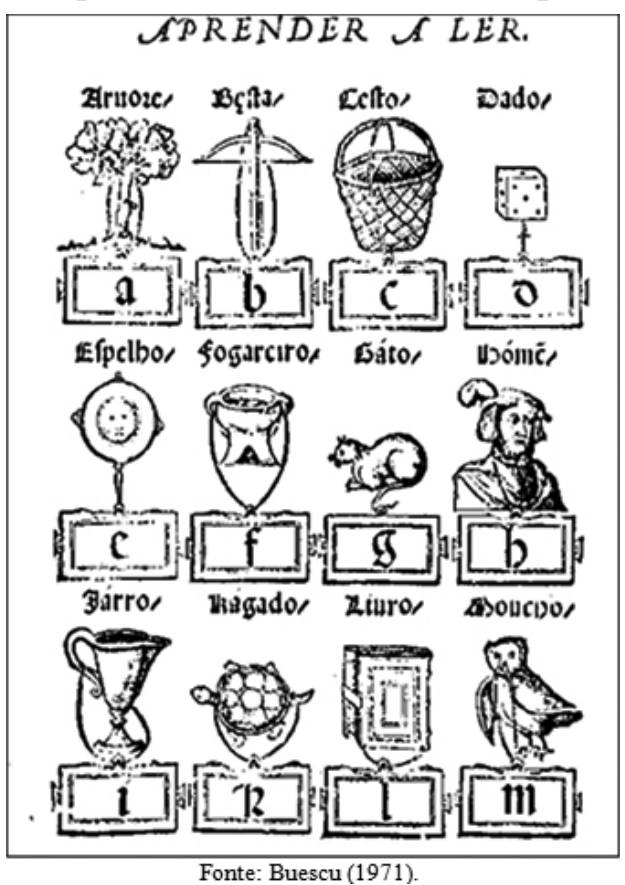

Tal vigor pode ser identificado no cabeçalho de cada lição do livro didático Porta aberta, quando se observa o destaque dado à letra inicial (Figura 2a), em suas formas maiúscula e minúscula, de imprensa e cursiva, e quando se verifica a exploração da palavra destacada na lição, associada a uma imagem que representa o ser que ela nomeia (Figura $2 b$ ). Embora, no livro recente, não seja seguida a ordem alfabética ${ }^{15}$, como ocorria na lição da Cartinha para aprender a ler, aquele segue o discurso linguístico que passou a considerar uma gradação quanto ao valor sonoro e fonético, ainda no século XXI ${ }^{16}$. Outras atividades presentes nas páginas deste livro também demonstram a preocupação em trabalhar com o reconhecimento de letras. Entre tais atividades, ganham destaque o recorte de letras de jornais, a pintura com cores diferentes de consoantes e vogais, a identificação da letra inicial do nome próprio de um colega ou do nome de objetos. Percebe-se, assim, que, dentro de uma nova roupagem, tida como mais recente, o reconhecimento de letras se mantém como um conhecimento importante em propostas didáticas contemporâneas. 
Figura 2 - Cabeçalhos ${ }^{17}$ de lição do livro Porta aberta

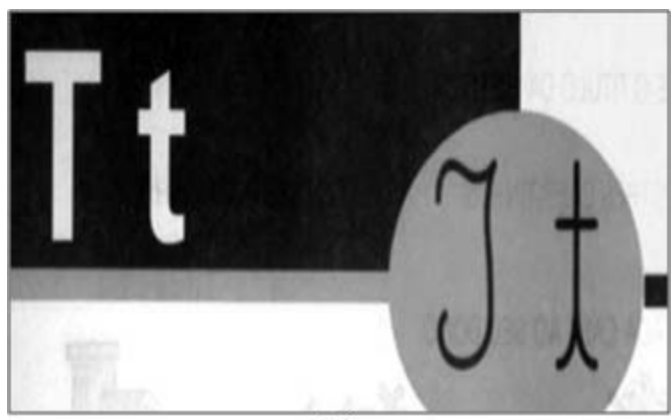

(a)

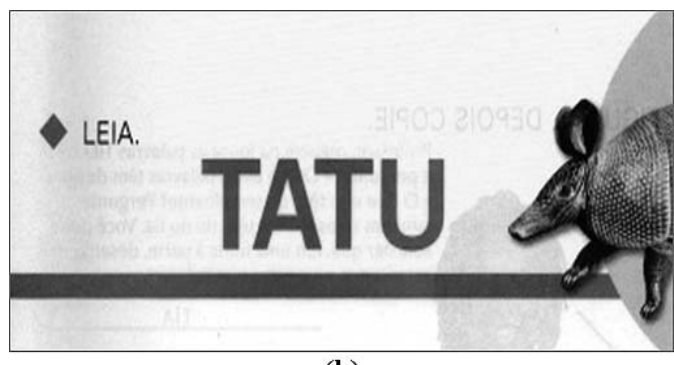

(b)

Fonte: Carpaneda; Bragança (2008, p. 52; p. 53).

Esse mesmo vigor - à nomenclatura das letras - pode ser reconhecido também em um dos itens avaliados pela Provinha Brasil ${ }^{18}$ - reconhecer letras, presente em muitas questões desse instrumento avaliativo, seja por meio de habilidades como identificar letras que possuem correspondência sonora única em palavras ou reconhecer pelo nome as letras do alfabeto. A questão três, da edição de 2010/Teste 2 (Figura 3) - Faça um X no quadradinho da primeira letra da palavra TUCANO ${ }^{19}$ ilustra a avaliação de tal conhecimento.

Figura 3 - Questão 7 da Provinha Brasil: caderno do aluno: teste 2

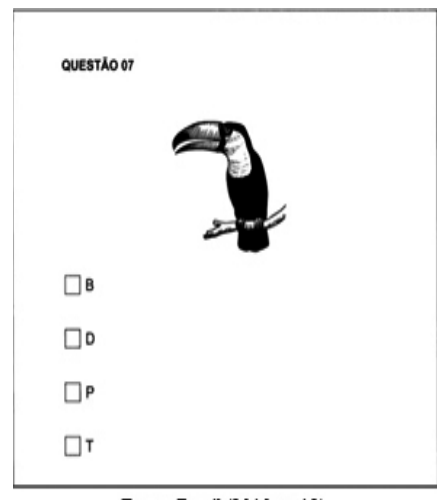

Fonte: Brasil (2010, p. 12). 
A Atualização dos Primeiros Métodos de Alfabetização...

Por meio desse primeiro exame de uma das lições do livro Porta aberta ${ }^{20}$, localizamos o valor dado ao reconhecimento das letras quanto ao aspecto gráfico - isto é, as diversas possibilidades de grafar uma mesma letra, assim como a associação de cada letra a uma imagem e a uma palavra representada por tal imagem, o mesmo ocorrendo na questão da Provinha Brasil, ao avaliar esse item ${ }^{21}$. Ou seja, com o exame desses artefatos escolares contextualizados como produtos pedagógicos contemporâneos, mostramos a continuidade do valor dado ao reconhecimento do alfabeto desde o século XVI, a partir do discurso linguístico, o que também já faziam as propostas de alfabetização construtivistas ${ }^{22}$, ao final do século XX, a partir do discurso psicolinguístico. As perspectivas construtivistas, neste sentido, davam destaque para a letra inicial e final dos nomes próprios e de outras palavras significativas, reconhecidas como formas fixas, organizadas em alfabetários expostos nas paredes da sala de aula e/ou colados na classe do aluno e/ou no seu caderno e explorados em jogos, ditados e outras atividades de sistematização, destacando ora a letra ora a sílaba.

Cagliari (1999), ao reconhecer que é mais comum na formação docente que se aprenda como ensinar do que o que ensinar, enumera um conjunto de noções básicas que deveriam ser ensinadas aos alfabetizandos no que se refere ao reconhecimento das letras, quais sejam: “escreve-se com letras” (p. 140), “[...] o alfabeto é um conjunto de letras” (p. 141), "a letra é uma unidade abstrata” (p. 142), “[...] o valor funcional das letras é dado pela ortografia” (p. 143), "importa aprender o nome das letras” (p. 144). Ou seja, os métodos de soletração antiga e de soletração moderna que foram apropriados posteriormente por uma nova ordem discursiva, sob a denominação de métodos alfabéticos permanecem, enquanto discurso didático sobre o processo de apropriação do sistema de escrita, em propostas contemporâneas de alfabetização.

\section{Da Análise da Palavra Falada à Palavra Escrita}

Retomamos a análise dos antigos métodos de alfabetização, agora, focalizando outro método, o da não soletração ${ }^{23}$, isto é, o da análise da palavra falada ${ }^{24}$.

Tanto Cirne Júnior (1973) quanto Lage (1924) pensavam que teria sido António Feliciano de Castilho quem, em Portugal, na década de 50 do século XIX, com seu método de ensino da leitura, teria rompido com os velhos processos da soletração antiga e moderna. Cirne Júnior (1973) observa que, após um período áureo em Portugal do Método Castilho, quando, então, ele caiu no descrédito e no esquecimento, o desprezo da ordem tradicional e o princípio da fragmentação do alfabeto - a sua divisão em partes, conforme seus valores - ainda, assim, não foram esquecidos.

Castilho (1854b, p. 28) sugere o uso da leitura auricular, que consistiria "na análise severa da palavra falada". Essa leitura consistiria na 
iniciação dos alunos no ritmo e, com ela, "quer-se habituar os alunos a obedecer aos sons, aos gestos e à cadência" (Lage, 1924, p. 46).

\begin{abstract}
[...] o professor profere as palavras destacando as sílabas uma por uma de modo a torná-las bem perceptíveis, e os alunos vão repetindo as mesmas palavras ao modo vulgar, isto é, sem essa separação de sílabas, tendo o cuidado de bater as palmas ao proferir a sílaba tónica. [...] Da decomposição da palavra em sílabas, o professor passa à distinção dos elementos de uma palavra. Vejamos exemplos dessas duas situações da 'leitura auricular'. O professor diz: escola. Os alunos repetem (em côro): escola e batem as palmas ao proferir a sílaba có. [...] O professor diz: $P, \hat{a} ; r, \hat{e}$; d, e. O côro repete: Pâ, rê, $\boldsymbol{d e}$; Parede (Lage, 1924, p. 46-47).
\end{abstract}

Tais exemplos mostram como se dá a passagem da decomposição da palavra em sílabas para a distinção dos elementos de uma palavra. $\mathrm{O}$ último passo, então, seria o da leitura ocular, isto é, do "[...] ensino dos sinais gráficos os quais representam os sons que o aluno já conhece” (Lage, 1924, p. 48). Castilho (1854a) sugeria que, logo que as crianças soubessem dividir a palavra nos seus elementos fônicos, usassem-se quadros contendo estampas destinadas a dar a ideia da forma e do som da letra (1854c). Assim: "A história da figura, de que a letra é a sombra, deve ser contada de modo mais atrativo, mais claro, mais verossímil, e que melhor concorra para darem á letra respectiva o valor ô valores que ela tem” (Lage, 1924, p. 23). As figuras e suas sombras (as letras) distribuíam-se em seis lições.

Castilho (1854b) explica que a distribuição das letras nas lições não seria organizada pela ordem convencional do alfabeto, mas pela apresentação inicial das letras substantivas, que seriam as vozes (primeira lição) e, após, das adjetivas, que seriam as inflexões, não pelas suas famílias, mas escolhendo, primeiro, quatro consoantes que não fossem próximas em valor (segunda lição) e, em seguida, consoantes que se parecessem na grafia (terceira lição), consoantes que representassem valores idênticos (quarta lição), voltando, após, às vozes, agora as nasaladas (quinta lição). As lições terminariam com o $h$, que não seria apresentado como letra e, sim, como sinal e, às vezes, sem valor (sexta lição). Ilustramos, a seguir, como seria desenvolvida na primeira lição a apresentação de uma das vozes, o $a$, através de uma história.

Por exemplo, para a letra a, o quadro contém a imagem de um rapasito encostado a um tronco em uma atitude de acordar, bocejando o som Á. E, como sombra desta imagem, vê-se ao lado, a letra $a$.

A propósito de cada figura conta-se uma história destinada a estabelecer a relação entre a letra e seu valor. [...]

O madraço do rapazinho encosta-se às árvores e passa os dias a bocejar fazendo $\grave{a}, \grave{a}, \grave{a} . . . . ;$ por isso lhe fixam chamando à, nome que devemos dar a vogal representada na sua sombra (Lage, 1924, p. 48). 
Figura 4 - Quadro da letra a do Método Castilho ${ }^{25}$

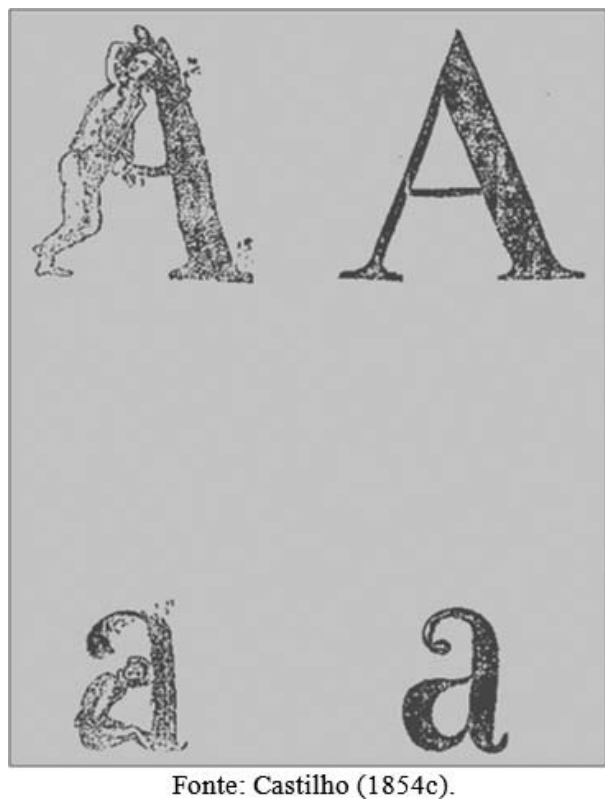

Assim, com as letras que as crianças vão conhecendo passam a ser escritas palavras, pequenas frases no quadro, as quais o coro lê cantando. Só depois de toda a exploração dos cartazes, passa-se à leitura no livro. No exemplo acima, pode-se verificar como seriam trabalhadas as lições após o primeiro momento, da leitura auricular, e também exemplifica-se a exploração da mnemonização ${ }^{26}$.

Os exemplos apresentados antes, por meio de trechos das orientações dadas pelo Método Castilho sobre a exploração da palavra falada em um método que a subdividiria em sílabas orais- leitura auricular-, podem ser aproximados a aspectos localizados em propostas de alfabetização presentes nas atividades do livro Porta aberta (Figura 5) e nas questões da Provinha Brasil (Figura 6), na medida em que tais atividades e questões dão destaque à divisão das palavras em sílabas. Inúmeras a cada lição e a cada teste, essas atividades e questões representam, sempre, repetições da relação entre imagem do objeto e escrita e/ou leitura, nos exercícios do $1^{\circ}$ livro, ou somente da repetição da relação entre imagem do objeto e leitura, nas questões da Provinha. Vejamos, então, cada uma delas de forma mais detalhada. 
Figura 5 - Atividades do livro Porta aberta

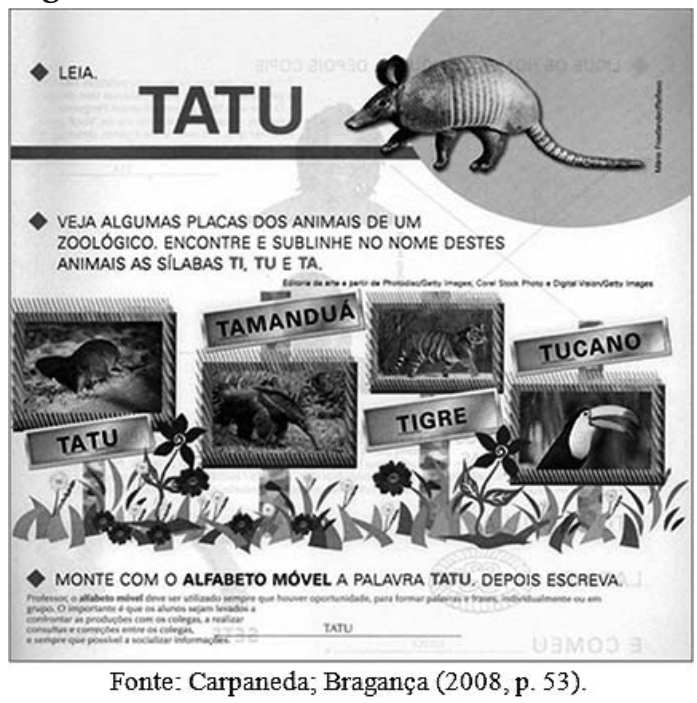

No livro Porta aberta, ao analisarmos as atividades ilustradas acima (Figura 5), percebemos a presença de uma proposta de leitura (primeira atividade) complementada por uma proposta de escrita (segunda atividade), a partir da utilização das letras do alfabeto. Na primeira proposta, o foco está no reconhecimento de palavras que iniciam por sílabas simples (ta, ti e tu). Na segunda, o foco está na escrita de uma palavra formada por duas dessas sílabas (ta e tu). Orientações didáticas acompanham tais atividades e ilustram como o discurso psicogenético sobre a apropriação do sistema de escrita repercute na exploração a ser feita do alfabeto - por meio das letras móveis ${ }^{27}$ - como instrumento para a produção escrita de palavras, na medida em que enfatiza a importância de reconhecer as letras para poder formar palavras, refletindo-se sobre a estruturação das suas sílabas.

Professor, o alfabeto móvel deve ser utilizado sempre que houver oportunidade, para formar palavras e frases, individualmente e em grupo. O importante é que os alunos sejam levados a confrontar as produções com os colegas, a realizar consultas e correções entre os colegas, e sempre que possível a socializar informações. Fonte: Carpaneda e Bragança (2008, p. 53) [primeira nota dessa página].

Professor, neste tipo de atividade, é interessante agrupar os alunos em duplas, considerando-se suas competências em relação às hipóteses sobre o sistema de escrita. Por exemplo: alunos em hipótese pré-silábica com alunos em hipótese silábica, alunos em hipótese silábica com alunos em hipótese silábico-alfabética. A escolha das palavras fará com que os alunos voltem sua atenção para o miolo das palavras, procurando descobrir o que as diferencia, uma vez que têm número aproximado de letras, começam e terminam com as mesmas letras. Fonte: Carpaneda e Bragança (2008, p. 53) [segunda nota dessa página]. 
Se, por um lado, uma mesma página do livro Porta aberta pode apresentar atividades de diferentes níveis de complexidade envolvendo as habilidades de leitura e de escrita, por outro lado, na Provinha Brasil, a cada página é apresentada, preferencialmente, uma única questão, a qual prioriza a avaliação dos eixos referentes à apropriação do sistema de escrita è leitura. Nesse sentido, observamos que há um investimento na Provinha Brasil com relação ao item Identificar o valor sonoro das partes inicias elou finais de palavras (algumas letras e sílabas), para "adivinhar" " "ler" o restante da palavra, a partir dos descritores: reconhecer sílabas e estabelecer relação entre unidades sonoras e suas representações gráficas $^{28}$. Com vistas à execução desse item, o aluno é avaliado em diferentes habilidades que passam pela identificação de sílabas (canônicas e não canônicas) no início, no meio e no final de palavras, pela identificação do número de letras de determinadas palavras e pela comparação de sílabas, a partir de imagens e/ou palavras diferentes. Enfim, parece que esse instrumento avaliativo vem dando importância à consolidação das correspondências grafofônicas e à análise fonológica, uma vez que as questões avaliadas nos testes visam comparar as sílabas das palavras quanto a semelhanças e diferenças sonoras, identificar sílabas e suas correspondências sonoras e analisar palavras quanto ao tamanho, por meio da contagem do número de sílabas. Exemplificando a avaliação do reconhecimento de sílabas, a questão 3, da edição de 2009c/Teste 2 (Figura 6), apresenta o seguinte comando no guia de aplicação do Caderno do professor: Veja a figura. Qual a primeira sílaba do nome da figura que você viu?

Figura 6 - Questão 3 da Provinha Brasil: caderno do professor: teste 2

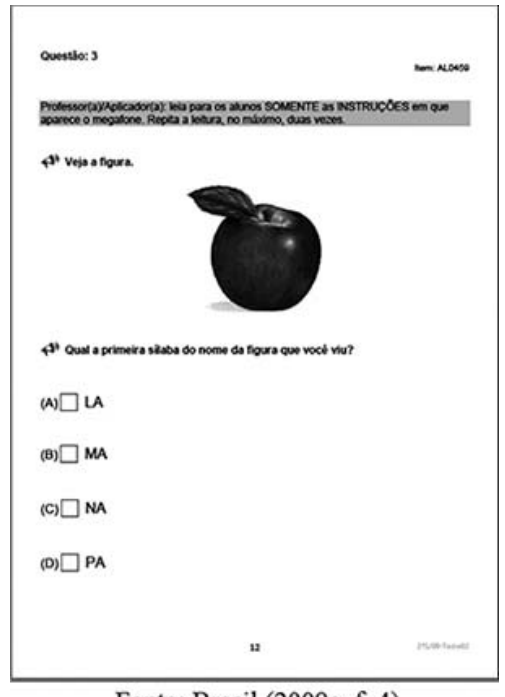

Fonte: Brasil (2009c, f. 4). 
As atividades acima apresentadas dão destaque, desde a Cartinha para aprender a ler e o Método Castilho, a uma associação mnemônica entre a imagem de um objeto e a palavra que nomeia tal objeto, como ilustram as imagens $1,2,3,4,5$ e 6 , possibilitando, a partir dessa associação, reconhecer a letra ou a sílaba inicial ou decompor a palavra em sílabas e letras. Tal associação faria parte de um investimento na imagem, visando a facilitara aprendizagem da leitura. Nesse sentido, os estudos de Vallange (Juanéda-Albaréde, 1998), em 1719,sugeriam o uso de figuras símbolos, que poderiam ser associadas aos sons da língua e, assim, acelerariam, de forma agradável, a memorização desses sons.

Lembramos que Ferreiro e Teberosky (1985) nos levam a avançar no exame da relação entre imagem e texto, ao pontuarem que os textos poderiam corresponder tanto ao nome de um objeto total, isto é, a sua designação habitual, quanto a uma parte do objeto, enquanto que a imagem apareceria representando objeto total; a uma subclasse, enquanto que a imagem apareceria representando a classe total, ou o inverso; ao nome de um dos objetos de uma sugestão de ação. As autoras exploraram essas discordâncias a fim de avaliar melhor o quanto os sujeitos pesquisados faziam uso das imagens ao decifrar o conteúdo do texto. As atividades que apresentamos anteriormente e estão presentes nas lições da Cartinha para aprender a ler, nos quadros do Método Castilho, nas atividades do livro Porta aberta ou nas questões da Provinha Brasil ilustram problemas com os quais as crianças podem se defrontar no uso da imagem como elemento auxiliar da leitura.

Mais uma vez, as noções propostas por Cagliari (1999) podem ser localizadas como remanescentes dos conceitos linguísticos em que se baseavam os métodos tradicionais, desde que atualizados em propostas contemporâneas, ao possibilitar aos alfabetizados: "reconhecerem-se como falantes da língua portuguesa” (p. 135), “[...] identificarem que a fala aparece na escrita segmentada em palavras” (p. 137), “[...] perceberem a palavra enquanto unidade de significados na sua relação entre ideias e sons e entre letras e ortografia” (p. 138), “[...] controlarem esses significados ao segmentar os enunciados em palavras e destas em unidades menores como sílabas e segmentos fonéticos do tipo vogal e consoante" (p. 139).

\section{Do Principio Alfabético ao Principio Ortográfico de Escrita}

Tendo apresentado João de Barros e António Feliciano de Castilho, passamos, agora, à apresentação de João de Deus e do seu método de ensino da leitura, conhecido através da publicação da Cartilha maternal (Deus, 1876).

Seguindo o mesmo princípio de seu predecessor, na classificação usada por João de Deus (1876) ${ }^{29}$ as vozes corresponderiam a elementos que se proferem simplesmente com a voz; os vozeios, por sua vez, corresponderiam aos elementos que se proferem com a voz modifica- 
A Atualização dos Primeiros Métodos de Alfabetização...

da pela língua, dentes ou lábios; já os bafejos correspondem a elementos que se proferem só com bafo; por fim, os modos correspondem a elementos sem som apreciável, limitando-se a posições essenciais da língua ou dos lábios (Lage, 1924). Quando João de Deus apresenta toda essa classificação para os elementos da fala - vozes, vozeios, bafejos e modos - está mostrando como deveria se dar o estudo da fala. O autor considerava que tal conhecimento exigiria muito mais do professor que da própria criança, já que aquele conduziria a análise fonética, de forma dialogada, com seus alunos, ensinando as regras e os diversos valores que poderiam ter as letras, dependendo da sua posição na palavra.

Relacionando a denominação que usamos para representar os símbolos gráficos com a representação adotada por João de Deus para identificar os elementos da fala, poderíamos concluir, de forma simplificada, que as vogais escritas corresponderiam às vozes e todos os seus valores fônicos e as consoantes corresponderiam aos demais elementos discretos da fala - vozeios, bafejos e modos - e todos os seus valores fônicos ${ }^{30}$.

O plano do Método João de Deus deveria ser segmentado em três partes: a primeira parte dizia respeito ao ensino das vogais $(a, e, i, o$, $u$ ), já constituindo palavras pelas suas combinações, e corresponderia à primeira lição; a segunda parte seria composta pelo conjunto de 23 lições e envolveria o estudo das consoantes certas $(v, f, j, t, d, b, p, l, k$, $q)$, das consoantes incertas $(c, g, r, z, s, x, m, n)$, das consoantes compostas certas $(t h, r h, n h, l h, p h, c h)$ e da consoante composta incerta $(y)$; a terceira e última parte, formando a $25^{\mathrm{a}}$ lição, trata da apresentação do alfabeto maiúsculo (Deus, 1876, p. 104) ${ }^{31}$.

Vencida a primeira parte do plano e a primeira lição, que corresponderia ao ensino das vogais, amplamente justificado por João de Deus, temos a segunda parte, abrangendo o estudo de todos os valores das consoantes certas, incertas e compostas certas e incertas. Para o autor, a escolha do $v$ para a segunda lição (Figura 7) se daria por ser esta uma das consoantes mais perfeitas, pois a sua sonorização "[...] é tão prolongável como as vogais” (Deus, 1876, p. 12-13). Sugere que a letra seja chamada por $v \hat{e}$ ou pelo que ela vale: $v$... Onze palavras são apresentadas nessa lição: v/vá, vai/vi, viạ, viu/vivii, vivia/viveu, viva/uva/viúva. Vejamos a orientação que o guia incluído na primeira edição da Cartilha maternal apresenta para essa mesma letra e valor:

\section{SEGUNDA LIÇÃO}

[...] Vamos agora combinar com as vogaes uma das consoantes mais perfeitas que é o v; porém não lhe haveis de chamar ú-consoante, que é uma falsidade, e vai desmentir todas as combinações. Chamai-lhe como se usa modernamente, vê, ou ainda melhor, e por ora, chamai-lhe o que elle vale, simplesmente v... pronunciando sem despegar o beiço inferior dos dentes de cima, sem vogal, sem voz, o simples sopro áspero e sonoro. 
Ensinai a proferil-o; e depois não tendes mais que ir apontando na palavra sucessivamente as letras que ides lendo, demorando-vos na pronuncia de cada uma o tempo que quizerdes, porque essa consoante é tão prolongavel como as vogaes (Deus, 1876, p. 12-13).

Figura 7 - Segunda lição (v) da Cartilha maternal

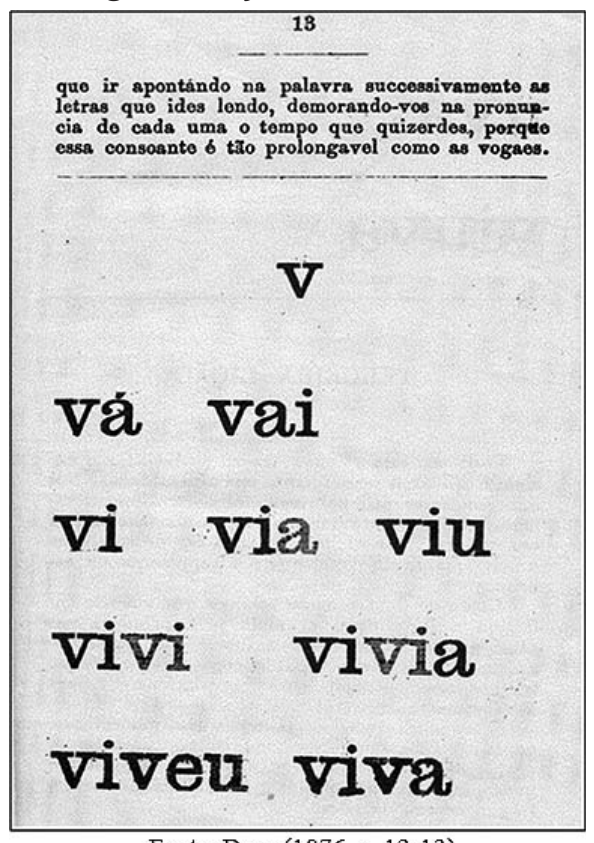

Fonte: Deus (1876, p. 12-13).

Considerando-se a produção francesa sobre a pedagogia da leitura dos séculos XVIII e XIX, observa-se que, se, por um lado, João de Deus (1876) julgava que o uso da imagem distraía o foco da criança da palavra, por outro, tal como Abbé de Radonvilliers (1768) e Nicolas Adam (1779-1787), tal uso favoreceria a compreensão da leitura. Ao preservar a unidade da palavra sem decompô-la em sílabas e ao propor o uso de tons que iriam do preto ao cinzento e do liso ao lavrado na representação gráfica das letras, o autor português inovaria em relação aos autores franceses, como Sénéchal (1859), que sugeria o uso das consoantes na cor vermelha e das vogais na cor preta, visando facilitar a comparação e as combinações para a formação de sílabas e palavras, enquanto Chavée (1872) propunha o uso de cores distintas nas letras que representassem diversos sons das vogais (Juanéda-Albaréde, 1998).

João de Deus defendeu, de forma precursora, a existência de regras para o domínio da arte da leitura, conforme ilustramos antes por meio das três partes do seu plano - ensino das vogais e das consoantes certas e incertas. Acreditando que a vertente linguística teria mais a contribuir na formação técnica de alfabetizadores do que a pedagogia 
A Atualização dos Primeiros Métodos de Alfabetização...

e a psicologia, Cagliari (1999) lista um conjunto de 29 regras de caráter linguístico, das quais já mencionamos algumas. Destacamos, agora, aquelas em que o autor distingue dois princípios: o acrofônico e o ortográfico. O primeiro princípio corresponde ao domínio do sistema alfabético da escrita, que opera como "chave da decifração da escrita" (p. 145), devendo ser ele ferramenta fundamental para o ensino inicial da leitura e da escrita, enquanto o segundo princípio exerce o controle da variação ortográfica das letras. Em suas palavras (Cagliari, 1999, p. 147):

\begin{abstract}
A ortografia controla completamente o alfabeto, inclusive o valor fonético que as letras têm[...] O uso 'alfabético' do alfabeto, ou seja, quando as letras representam sons independentemente das palavras (ortografia), gera o que se chama de 'transcrição fonética'. [...] Em um primeiro momento, para dar mais liberdade e incentivar os alunos, escritas desse tipo devem ser feitas. Porém, é importante que seja dada uma boa explicação sobre a variação linguística e sobre a ortografia, para que os alunos não fiquem pensando que o modo como estão escrevendo é o ponto de chegada.
\end{abstract}

Ferreiro e Teberosky (1985) nos dirão que chegar ao nível alfabético $^{32}$ da escrita, ao identificarem cinco níveis psicogenéticos na apropriação do sistema de escrita, implicaria que a criança tivesse franqueado a barreira do código no sentido estrito, alertando, porém, que outras dificuldades precisariam ainda ser superadas a partir desse momento, como aquelas que são próprias da ortografia. Nesse sentido, Cagliari (1999) esclarece de forma detalhada, em suas 29 regras sobre o que é preciso saber para ler, que "[...] as relações entre letras e sons (ou seja, a leitura) são diferentes das relações entre sons e letras (ou seja, a escrita)" (p. 148), mostrando que a ortografia, ao controlar a variação gráfica das letras, neutraliza a variação linguística na escrita; tal variação está presente e é plenamente aceita na oralização da leitura na própria fala.

Mais uma vez o livro didático Porta aberta nos traz ilustrações atuais do que foi analisado acima. Em uma atividade da página analisada (Figura 8) é solicitado ao estudante que identifique entre as palavras sete, oito, peteca e bola, duas palavras que rimem com as representadas no texto, por meio da respectiva figura (biscoito e boneca). Nesta atividade, a leitura da palavra é trabalhada globalmente, não havendo em nenhum momento a exploração da sua segmentação silábica ${ }^{33}$. Ressaltamos que já na apresentação da primeira consoante, as palavras, além de seguirem uma estrutura CVCV (bola), alternam para VVCV (oito), e as palavras formadas por sílabas complexas são introduzidas gradualmente ao longo das unidades ${ }^{34}$. Ganha destaque nesta atividade a nota de pé de página que remete para uma preocupação com o trabalho com as rimas; pode-se inferir, assim, que, além da utilização da imagem como auxiliar da leitura, temos também a utilização das rimas como outro facilitador do processo.

844 Educação \& Realidade, Porto Alegre, v. 40, n. 3, p. 829-857, jul./set. 2015. 
Professor, antes da atividade, retome com os alunos o conceito de rima e proponha uma brincadeira com sons de algumas palavras. Por exemplo: eca, meleca, cueca, careca, sapeca/ rata, lata, pata/ oito, biscoito, dezoito/ escola, cola, vitrola, esmola, camisola/ pirulito, palito, mosquito, periquito, cabrito, apito/ chinelo, martelo, marmelo, cogumelo, farelo, amarelo.” Fonte: Carpaneda; Bragança (2008, p. 53) [Nota da página 54 referente a essa atividade]

\section{Figura 8 - Atividades do livro Porta aberta}

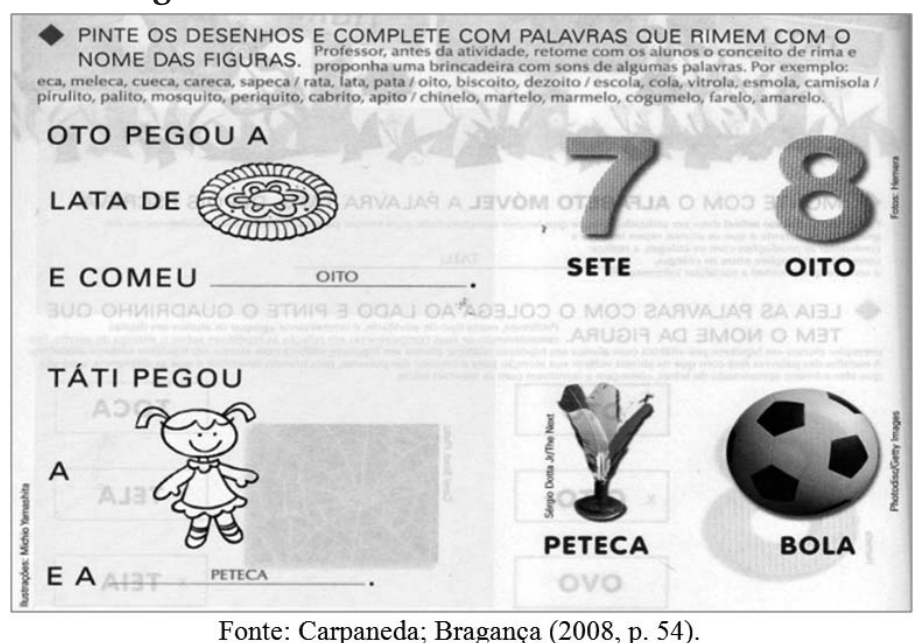

Em relação a Provinha Brasil - continuando a fazer o pareamento com os métodos iniciais da leitura - observamos também o investimento no item ler algumas palavras compostas por sílabas formadas por consoante/vogal/consoante (sílabas canônicas) ou por consoante/consoante/vogal (sílabas não canônicas), através do descritor ler palavras. Enquanto a questão 1 da edição de 2008/Teste 1 (Figura 9) focaliza a avaliação da leitura de palavra formada por sílaba canônica - Faça um $X$ no quadrinho onde está escrito FACA, a questão 6 da edição de 2008/ Teste 2 (Figura 10) focaliza a avaliação da leitura de palavra formada por sílaba não-canônica - Faça um X no quadrinho onde está escrito FORMIGUINHA. 
Figura 9 - Questão 1 da Provinha Brasil: caderno do aluno: teste 1

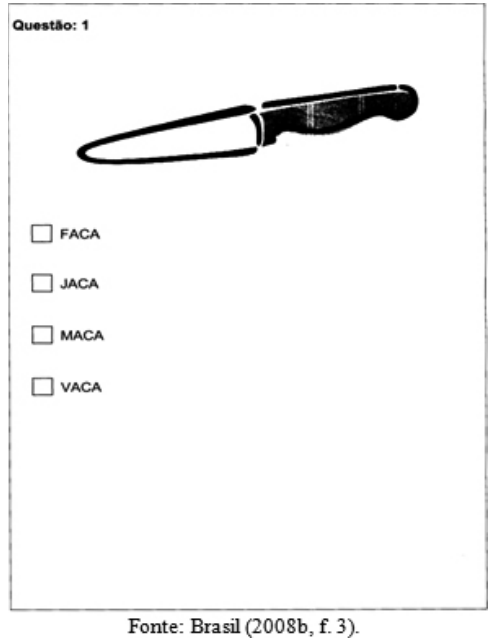

Figura 10 - Questão 6 da Provinha Brasil: caderno do aluno: teste 2

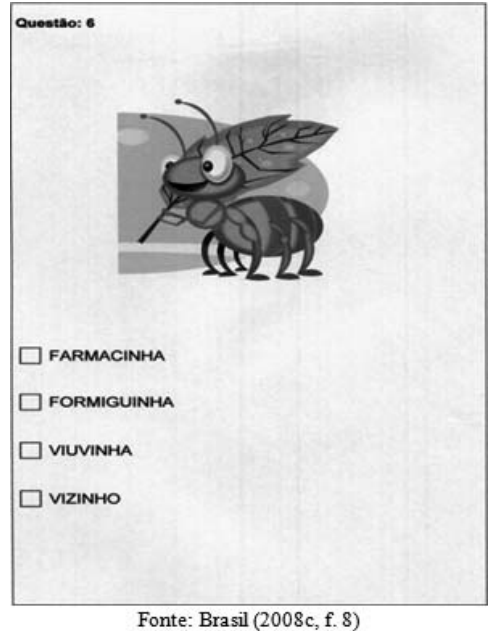

Com vistas a dar visibilidade aos princípios alfabético e ortográfico, a Figura 9 mostra uma questão que ilustra o primeiro princípio (alfabético) ao avaliar a habilidade - Ler algumas palavras compostas por sílabas formadas por consoantelvogal (sílabas canônicas). Já a Figura 10 mostra, por sua vez, uma questão que ilustra o segundo princípio (ortográfico) ao avaliara habilidade - Ler algumas palavras compostas por silabas formadas por consoante/vogal/consoante (sílabas canônicas) ou por consoante/consoante/vogal (sílabas não canônicas) ${ }^{35}$. Nesse sentido, salientamos que há uma complexidade menor ou maior quanto às habilidades avaliadas em diferentes questões, ora visando ao domínio 
alfabético do nosso sistema de escrita, isto é, a leitura de palavras formadas somente por sílabas simples, ora visando ao domínio das normas ortográficas da nossa língua, isto é, a leitura de palavras formadas por sílabas complexas ${ }^{36}$.

\section{Algumas Observações e Provocações Finais}

Três cartilhas de alfabetização, criadas entre 1496 e 1896, serviram de ponto de partida para a análise de atividades da produção didática contemporânea na área da alfabetização, representadas por uma lição de um livro didático de 2010 e questões de testes utilizados em 2008 e 2010, nas escolas públicas brasileiras. Ao longo do texto, as primeiras foram comparadas com as produções contemporâneas, que, de certa forma, atualizam suas propostas didáticas e as avaliam. Graças ao reconhecimento da originalidade dessas três primeiras obras didáticas e das rupturas que causaram, cada uma em seu tempo, nas práticas pedagógicas então em uso, pudemos compreender a trajetória inicial de métodos de alfabetização, marcados por aparatos dos quais fazemos uso em propostas contemporâneas de alfabetização. Tal reinvenção pôde ser identificada em materiais didáticos produzidos e avalizados por políticas públicas como a do Programa Nacional do Livro Didático (PNLD 2010), ao distribuir livros para uso nas escolas públicas selecionados conforme os discursos mais recentes na área da alfabetização, e da Provinha Brasil, ao avaliar o desempenho de alunos em turmas de alfabetização dessas mesmas escolas públicas.

João de Barros produziu a Cartinha para aprender a ler no período em que a gramática iniciava a disciplinar a língua portuguesa, enquanto António Feliciano de Castilho e João de Deus participaram da discussão do seu processo de simplificação três séculos depois, criando métodos de ensino da leitura e da escrita, no caso do primeiro, e somente da arte da leitura, no caso do segundo. Observamos, ainda, que esses primeiros métodos de ensino da arte da leitura e da arte da escrita ${ }^{37}$, uma vez que focavam somente uma dessas artes ou ambas, passam a ser reposicionados em novas ordens metodológicas, dependendo da forma como são interpretados quanto à ênfase dada a cada uma das unidades linguísticas e às suas combinações nas propostas contemporâneas. Vemos isso em cada atividade proposta ou questão a ser avaliada, as quais, a partir de uma nova ordem discursiva, passam a agrupar o reconhecimento de letras, sílabas e fonemas como unidades linguísticas no eixo apropriação do sistema de escrita, e o reconhecimento de palavras, no eixo leitu$\mathrm{ra}^{38}$, no caso da Provinha Brasil. Vemos, ainda, que esse agrupamento é diferente do que ocorre nas orientações do PNLD, pois neste o eixo letramento inclui somente a leitura e produção de textos, cabendo ao eixo alfabetização linguística explorar o reconhecimento de letras e de sílabas e a de/codificação de palavras formadas por sílabas mais simples ou mais complexas. Ou seja, assim como no início da disciplinarização da 
língua portuguesa e da invenção dos primeiros métodos de alfabetização, atualmente categorizações diversas orientam a produção de material didático, a partir dos discursos circulantes e das interpretações que eles recebem nos documentos oficiais.

Nos limites do que ainda podemos dizer neste artigo, a análise dos artefatos didáticos apresentados e colocados em suspeição, permitiu-nos desnaturalizá-los, para, então, retomá-los como artefatos contextuais e históricos, os quais trazem marcas da trajetória da produção discursiva destinada à alfabetização e à sua avaliação. Procuramos, dessa forma, ilustrar, por um lado, a permanência dos discursos desses primeiros métodos de ensino da leitura e da escrita, e, por outro lado, a forma como eles são objetivados, por meio da análise de propostas didáticas de um dos livros didáticos de $1^{\circ}$ ano da coleção Letramento e alfabetização linguística, do PNLD 2010, e de questões da Provinha Brasil.

Assim, com base na tese de Silva (2012), percebemos que, no livro Porta aberta, as atividades pinçadas parecem focalizar predominantemente a sistematização do código escrito, uma vez que sua proposta didática, no que se refere ao eixo alfabetização, traz elementos dos estudos sobre consciência fonológica e dos estudos baseados na psicogênese da língua escrita, sem esquecer aspectos referentes ao letramento, embora este último não tenha sido tratado nas análises apresentadas. Por sua vez, a partir da tese de Mello (2012), constatamos que, na Provinha Brasil, as questões selecionadas por meio dos descritores reconhecer letras e sílabas, a relação grafema-fonema e ler palavras com sílabas canônicas (consoante/vogal) e não canônicas (vogal/consoante/vogal), fazem parte do conjunto de itens que se dedicam à avaliação da apropriação do sistema da escrita e de um nível inicial de leitura ${ }^{39}$. Tais itens dão maior visibilidade ao desempenho dos alunos no eixo alfabetização. Ao que parece, enquanto o livro mais escolhido e utilizado na rede municipal de ensino de Porto Alegre dá destaque à sistematização do código escrito, as questões com maior acerto são as que priorizam a avaliação de sua aquisição, ilustradas neste estudo a partir das questões analisadas, envolvendo o reconhecimento de letras, de sílabas e de palavras. Dessa forma, parece que o material didático usado na alfabetização estaria contribuindo para a produção do desempenho avaliado, que, por sua vez, levaria à reprodução de atividades contidas nos livros didáticos ${ }^{40}$.

Por fim, deixamos, como provocações para futuras discussões e estudos, as seguintes questões:

1. Na medida em que a Provinha Brasil posiciona o reconhecimento de letras e o reconhecimento de sílabas no eixo apropriação do sistema de escrita e a leitura de palavras formadas por sílabas canônicas e não canônicas no eixo leitura, sendo que o primeiro eixo pertenceria à área alfabetização e o segundo, à área letramento, como poderíamos interpretar tal divisão desta última área em relação à classificação dos métodos em sintéticos e analíticos? Dito de outra forma: a área da alfa- 
betização, por meio do eixo apropriação do sistema de escrita passaria a responder em parte pelo ensino da leitura, somente no que se refere a reconhecer letras e reconhecer sílaba, cabendo à área do letramento, por meio do eixo leitura, responder pelo ensino da leitura no que se refere a ler palavras? Cabe discutir, então, que estudos sobre letramento amparariam tal divisão.

2. Se os estudos da psicogênese da língua escrita, ao examinarem a leitura e a escrita de palavras e frases, posicionam os sujeitos no nível alfabético quando apresentam o domínio do princípio alfabético, restaria a quais estudos orientar a ação dos professores para o ensino de um maior domínio das regularidades da língua escrita?

3. A alfabetização linguística, associada ao letramento, nas coleções aprovadas pelo PNLD 2010, pretendeu ressignificar os métodos sintéticos assim como os analíticos, dando novo vigor aos estudos sobre consciência fonológica, ao associá-los à implantação do ensino fundamental de nove anos?

A produção de respostas a essas questões depende de retomarmos a discussão sobre a produção do conhecimento de diversas áreas, sem assumirmos a pretensão de buscar a verdade única, mas talvez, isto sim, com vistas a indicar suas contribuições parciais, que, somadas, podem se multiplicar em qualidade para uma escolarização mais efetiva da alfabetização na contemporaneidade ${ }^{41}$.

Recebido em 31 de julho de 2013 Aprovado em 05 de março de 2014

\section{Notas}

1 Esta tese, a partir do campo dos Estudos Culturais e das contribuições dos estudos pós-modernos, pós- estruturalistas e da Análise Crítica do Discurso, em sua vertente foucaultiana, traz a análise dos discursos e representações que aparecem nas cartilhas ou primeiros livros de alfabetização, examinando também de que forma eles se harmonizam/circulam por outros discursos da época ou por narrativas que hoje se fazem deles/as. Metodologicamente, é privilegiada a interpretação textual, incluindo-se, além das cartilhas, outras fontes documentais, para contextualização desse período histórico. Tal tese ilustra como as cartilhas fizeram parte de uma cadeia de produção cultural, sendo sua intertextualidade marcada pelo impacto da interdiscursividade da modernidade republicana (Trindade, 2001; 2004).

2 Essas três obras didáticas serão apresentadas daqui para frente no texto, respectivamente, como Cartinha para aprender a ler, Método Castilho e Cartilha Maternal. Serão respeitadas as diferenças existentes entre a grafia do português do Brasil e de Portugal na transcrição de títulos e de trechos dos documentos analisados, o que implica respeitar também a grafia de época.

3 Esta tese analisa discursos circulantes nos novos livros de alfabetização, a partir dos princípios e critérios do Programa Nacional do Livro Didático (PNLD 2010), que guiaram a sua seleção. Para tanto, contou com a perspectiva teórica dos Estudos Culturais pós-estruturalistas e pós-modernos, para analisar o circuito 
A Atualização dos Primeiros Métodos de Alfabetização...

de produção, regulação e consumo dos discursos de alfabetização presentes tanto no Edital de Convocação e no Guia de Livros Didáticos, do PNLD 2010, quanto em quatro livros didáticos selecionados para o novo $1^{\circ}$ ano do Ensino Fundamental pertencentes à Coleção Letramento e alfabetização linguística, que foram os mais escolhidos pelas escolas da Rede Municipal de Ensino de Porto Alegre. Considerando os artefatos acima citados como parte do circuito de produção, regulação e consumo dos discursos sobre alfabetização e letramento nos livros didáticos selecionados pelo PNLD 2010, a análise permitiu constatar que as disputas entre métodos tradicionais e inovadores de alfabetização dão espaço a uma bricolagem deles, contando com o discurso sobre a consciência fonológica, que, por sua vez, é associado aos da psicogênese da língua escrita e do letramento, para produzir tal coleção (Silva, 2012).

4 Esse livro didático será apresentado doravante pelo seu primeiro título - Porta aberta.

5 As primeiras lições do $1^{\circ}$ livro Porto aberta apresentam as vogais e os encontros vocálicos, seguidos por lições que passam a apresentar as consoantes que diferem em relação ao seu ponto de articulação, seguindo a ordem t, p, l, b, n, c, d, m, v, s, r, f, g, j, x, z para, em seguida, trabalhar com as variáveis destas letras, inversões e sílabas complexas.

6 Palavras textuais do documento Guia de livros didáticos: PNLD 2010: letramento e alfabetização/língua portuguesa: “[...] o letramento e a alfabetização linguística, de um lado, e a alfabetização matemática, de outro, têm se revelado como demandas nucleares, o que lhes tem conferido o papel de eixos orientadores, tanto das reorganizações curriculares para o primeiro segmento [primeiro e segundo anos do EFNA], quanto da formação docente continuada, ou mesmo de avaliações oficiais de rendimento, como a Provinha Brasil" [acréscimos e grifos nossos] (Brasil, 2009a, p. 16). "Já na segunda etapa - que, no âmbito do PNLD, estende-se do terceiro ao quinto anos [do EFNA] - trata-se de levar o aluno à consolidação desse duplo processo de letramento e de alfabetização. Do ponto de vista dos eixos orientadores do processo de reorganização do ensino fundamental, esses três anos têm sido entendidos como o período de consolidação do processo de alfabetização linguística e matemática da criança” (Brasil, 2009a, p. 17) [grifos nossos].

7 A referida tese situa como corpus de análise a Provinha Brasil, avaliação diagnóstica do nível de alfabetização das crianças matriculadas no segundo ano de escolarização das escolas públicas brasileiras na contemporaneidade, nas edições de 2008 a 2011, Testes 1 e 2, problematizando-a. Essas problematizações foram orientadas por uma questão central: a análise da emergência da Provinha, em relação à sua finalidade e seus efeitos. A presença reguladora do Estado na gestão da educação, por meio das tecnologias numéricas de governamentalidade, considerando o uso desse termo nos estudos foucaultianos, a partir da estatística, é um elemento importante para tal análise. A avaliação, assim, nesta tese, é compreendida como uma dessas várias técnicas de controle, normalização e modelagem da conduta das pessoas, situada em relação a sociedades e a tempos determinados (Mello, 2012).

8 Palavras textuais retiradas do documento Passo a passo (Brasil, 2008a, p.9): "Apropriação do sistema de escrita - diz respeito à apropriação pela criança, do sistema da língua escrita. Isto é, trata-se da aquisição das regras que orientam a leitura e a escrita pelo sistema alfabético, bem como do domínio da ortografia da língua portuguesa [...]".

850 Educação \& Realidade, Porto Alegre, v. 40, n. 3, p. 829-857, jul./set. 2015. 
Trindade; Mello; Silva

9 Se, para soletrar pela soletração antiga, a palavra tinteiro seria soletrada como te $+i+\underline{e} n e=t i n, t e+e ́+i=t e i, \underline{r r r e}+o=r o$, pela soletração moderna, seria te + $i+\underline{n e}=$ tin, $t e+e ́+i=$ tei, $\underline{r e}+o=r o$.

10 Do método da nova soletração interessa a este estudo o destaque que passa a dar à análise das sílabas com vistas a mostrar a permanência deste tipo de análise nas propostas didáticas e avaliações contemporâneas.

11 Os itens avaliados para a elaboração desse material correspondem aos aspectos relativos aos eixos de ensino descritos no Guia de livros didáticos do PNLD 2010: letramento e alfabetização/língua portuguesa (Brasil, 2009a), os quais serviram de base tanto para a elaboração dos livros didáticos pelos autores e editoras quanto para os professores realizarem suas escolhas. Tais eixos, englobados pelas áreas de conhecimento alfabetização linguística e letramento, são subdivididos nas resenhas que avaliam cada livro didático em quatro itens: leitura, escrita, aquisição do sistema de escrita e oralidade.

12 Instrumento avaliativo aplicado semestralmente em turmas do $2^{\circ}$ ano do ensino fundamental das escolas públicas brasileiras desde o ano de 2008. Os itens avaliados correspondem ao eixo apropriação do sistema de escrita da matriz de referência da Provinha Brasil. A Matriz de Referência da Avaliação da Alfabetização e do Letramento Inicial "é apenas uma referência para a construção do teste" (Brasil, 2008c, p. 08) e com base nos significados atribuídos recentemente aos conceitos de alfabetização e de letramento, indica as habilidades a serem consideradas em tal instrumento avaliativo. Antecipamos que, dos cinco eixos - compreensão e valorização da cultura escrita, apropriação do sistema de escrita, leitura, escrita, e desenvolvimento da oralidade - das duas grandes áreas avaliadas - alfabetização e letramento -, somente um deles, no caso da primeira área - o eixo apropriação do sistema de escrita, e três deles, no caso da segunda área - compreensão e valorização da cultura escrita, leitura e escrita - foram avaliados na $1^{\text {a }}$ edição da Provinha Brasil-Teste 1 e 2, (Brasil, 2008c; Brasil, 2008a). A alegação para a ausência de determinados tipos de questões nos testes posteriores, a partir de 2009, é de que há limitações impostas pela natureza da avaliação - exclusividade de questões de escolha simples - usada para as questões do eixo leitura em todas as edições, e a necessidade de questões abertas - testada nas questões do eixo escrita somente na edição de 2008. Tal alegação se estende para explicara ausência de questões do eixo desenvolvimento da oralidade em todas as edições, justificada por limitações técnicas - categorizar respostas, estruturar grade de correção (Brasil, 2009b).

13 Além da Cartinha para aprender a ler, outras três obras de João de Barros, que formariam o corpus didático da época, em Portugal, estão inclusas como anexo em livro de Buescu (1971).

14 Reprodução fac-similada da primeira edição da Cartinha para aprender a ler de João de Barros, datada de 1539, inclusa em Buescu (1971). Conforme Juanéda-Albaréde (1998), João de Barros faria a introdução de figuras associadas ao som das letras iniciais das palavras em 1755, aproveitando a virtude pedagógica das ilustrações. Embora contemos com informações contraditórias sobre a data da introdução da imagem nessa Cartinha para aprender a ler, que talvez não tenha ocorrido em sua primeira edição, tal material didático acompanhou a inclusão da imagem no ensino da leitura.

15 Cf. nota 05.

16 Essa discussão será retomada quando examinarmos o Método Castilho e a Cartilha maternal, nas próximas seções. 
A Atualização dos Primeiros Métodos de Alfabetização...

17 Optamos pelo recorte das páginas em partes, com vistas a garantir uma melhor visualização das atividades. Neste primeiro recorte, ainda fizemos uma ampliação do que estava sendo destacado em dois cabeçalhos diferentes da primeira lição, mesmo que com o prejuízo do recorte da imagem do tatu.

18 De acordo com Schneider e Mozz (2011), de uma para outra edição da Provinha Brasil, poucas alterações foram evidenciadas no tocante à estrutura e ao tipo de questão. Tal observação leva as autoras a conferir um caráter de treinamento acerca do tipo de questão e das habilidades consideradas relevantes ao processo de alfabetização.

19 Tais ordens não aparecem no Caderno do aluno, mas somente no Guia que orienta a aplicação de cada teste, quando elas devem ser lidas em voz alta pelo professor aplicador.

20 Embora o livro Porta aberta trabalhe também com as questões relativas ao letramento, apresentando várias atividades que contemplam diversos portadores de textos e incentive o uso de diferentes gêneros textuais, estas não serão examinadas neste texto. Optamos por trabalhar apenas com as atividades de sistematização do sistema de escrita alfabética vinculadas ao discurso da $\mathrm{al}$ fabetização linguística. A adjetivação dada à alfabetização, ao incluir o termo linguística, leva-nos a reconhecer que a hegemonia cognitivista da psicogênese cede espaço à inclusão do discurso da consciência fonológica no que diz respeito à aquisição do sistema de escrita, sendo essa a grande novidade do PNLD 2010 em relação ao PNLD 2007.

21 A leitura de frases e textos curtos, o reconhecimento da finalidade e do assunto de diferentes suportes e gêneros textuais, como também a exploração da tipologia do texto narrativo e do uso de inferências, avaliadas pela Provinha Brasil, não serão examinadas neste texto, mesmo se fazendo presentes nos métodos de ensino analisados, por meio de textos presentes ao término de tais artefatos escolares, pois dependeriam da discussão da exploração didática de tais textos nesses e nos métodos que os sucederam, bem como da discussão de outros estudos contemporâneos, como os de letramento, associando-lhes os estudos sobre gêneros textuais e discursivos, entre outros.

22 Cf. Grossi (1990a, b, c).

23 O método da não soletração, centrado na leitura auricular da palavra, que consistia na sua segmentação oral em sílabas e letras, no caso do Método Castilho (1853), e na palavra lida por meio de regras fonéticas, no caso do Método João de Deus que orienta a produção da Cartilha Maternal (1876), a ser examinada na próxima seção, inaugura, dessa forma, um novo ponto de partida, e o reconhecemos hoje como método da palavração.

$24 \mathrm{O}$ valor dado à exploração da palavra por meio de rimas e aliterações ganhou vigor com a implementação do ensino fundamental de nove anos em virtude da crescente influência dos estudos sobre consciência fonológica, com os mesmos passando a ser discutidos na formação docente. Cf. Morais (2006).

25 Como podemos ver, António Feliciano de Castilho (1853) privilegiaria também a associação entre imagem e texto, como o fez João de Barros, apresentando, agora, uma história para cada letra e relacionando sua forma gráfica a um desenho que corresponderia à sombra de cada letra.

26 Como podemos observar, o conto e a análise fonêmica acompanham as lições do Método Castilho, desde a apresentação da primeira letra e sua voz, por meio

852 Educação \& Realidade, Porto Alegre, v. 40, n. 3, p. 829-857, jul./set. 2015. 
da leitura auricular; entretanto, tal método foi reconhecido à época como sem soletração, em oposição aos de soletração. Poderíamos categorizá-lo, assim como o foi o da Cartilha maternal, como método analítico-sintético, distinguindo, porém, o ponto de partida de cada um. A Cartilha maternal seguiria um método que teria como ponto de partida a palavra, como veremos, em seguida, enquanto o Método Castilho poderia ser ainda posicionado quanto à leitura ocular como um método que mesclaria a exploração da palavra e da sentença.

$27 \mathrm{O}$ alfabeto móvel consiste, frequentemente, em cartões formados por 36, 72 ou 130 peças, com as vogais em maior número, para uso em jogos didáticos. Quando está incluso nos livros didáticos, pode ser destacado e guardado em um envelope ou em outro tipo de embalagem para uso coletivo ou individual. Também pode ser adquirido comercialmente em outros materiais, como plástico, E.V.A. e madeira.

28 É pertinente destacar que, embora a $1^{\text {a }}$ edição da Provinha Brasil tenha sido em 2008, somente a partir da $3^{\text {a }}$ edição desse instrumento avaliativo (2010) é que aparece o item contar a quantidade de sílabas de palavras formadas por sílabas simples consoante/vogal.

29 A edição da Cartilha maternal usada para apresentar as lições (Deus, 1996) corresponde à cópia fac-similada da $1^{\mathrm{a}}$ edição (Deus, 1876).

30 Em propostas de alfabetização contemporâneas, encontramos a associação das vogais a personagens de desenhos infantis, identificando-as como super poderosas (Piccoli, 2009). Tal analogia se repete ao distinguir as vogais no alfabetário com uma cor diferenciada das consoantes ou ao ensinar aos alunos, como estratégia de jogo, que digam as vogais antes das consoantes, já que as primeiras estão sempre presentes nas sílabas.

31 Há, ainda, entre a décima sétima e a décima oitava lição a inclusão de um pequeno diálogo (p. 70-73) e, fazendo parte da 25a lição, há uma lista de palavras esdrúxulas (p. 120-121) antes da apresentação do alfabeto (p. 122-123). Após, há a inclusão de um segundo texto, o poema Hymno de amor (p.124-136).

32 Nomeado de princípio acrofônico por Cagliari (1999).

33 As palavras escolhidas, conforme o livro Porta aberta, deverão ser transcritas no espaço destinado a elas na página, o que mostra que a atividade de cópia, criticada pelos estudos da psicogênese, por meio da afirmação teórica "Não identificar escrita com cópia de um modelo externo" (Ferreiro; Teberosky, 1985, p. 273), ao atribuir aos métodos tradicionais de alfabetização o uso de tal recurso, permanece em uso em propostas contemporâneas.

34 Outras estruturas, como CVV (tia; tio), CVVV (teia), VCV (ovo), ou CVCCV (tigre) estarão alternando sílabas simples e complexas em palavras de uma mesma atividade ou de diferentes atividades de uma mesma lição, como essa primeira do livro Porta aberta.

35 Destacamos que das 19 questões que compõem o instrumento avaliativo da Provinha Brasil, período 2009-2010, testes 1 e 2, 18contaram com o apoio do desenho. Essas 18 questões apresentam sílabas complexas com presença de encontro consonantal e dígrafo, além de serem em sua maioria palavras trissílabas.

36 Observamos que as sílabas com dígrafo são evidentemente de mais difícil leitura e escrita do que as sílabas com encontros consonantais. A distinção sílabas canônicas e não canônicas - aplicada à escrita - mascara (ignora) a pre- 
A Atualização dos Primeiros Métodos de Alfabetização...

sença ou não de dígrafo, que representa importante obstáculo para o domínio ortográfico. No caso de "formiguinha" há essa dificuldade maior, porque na sílaba GUI há um dígrafo, o que é fundamentalmente diverso de uma sílaba $\mathrm{CCV}$, em que três letras representem três fonemas efetivamente produzidos, com encontro consonantal.

37 Cada uma dessas artes possuía métodos próprios, sendo que as produções didáticas se dedicavam ora à arte da leitura ora à arte da escrita. $\mathrm{O}$ ensino simultâneo da leitura e da escrita pode ser localizado em contrafações brasileiras reconhecidas como inconvenientes da obra original, no caso da Cartilha maternal, pois nesta última seu autor assume somente o ensino da arte da leitura.

38 Incluindo, ainda no eixo leitura, o reconhecimento de sentenças e, no que se refere a textos, o reconhecimento de sua finalidade, assunto, informações explícitas e implícitas, embora esses itens não sejam examinados neste artigo.

39 Relembramos que o PNLD 2010 usa a expressão área de conhecimento para se referir à alfabetização linguística e ao letramento, subdividindo-os, então, em quatro eixos - leitura, escrita, oralidade e aquisição do sistema de escrita-, enquanto a Provinha Brasil restringe o uso do primeiro termo à alfabetização e ao letramento, subdividindo-os, então, em cinco eixos-compreensão e valorização da cultura escrita, apropriação do sistema de escrita, leitura, escrita, e desenvolvimento da oralidade. Cf. notas 11 e 12.

40 O PNLD2010 a Provinha Brasilfazem parte do programa de formação continuada de professores Pró Letramento, iniciado a partir da implantação do ensino fundamental de nove anos, o qual estabelece a inclusão de mais um ano no início da escolarização nesse nível de ensino. O livro didático do PNLD 2010 examinado é o do $1^{\circ}$ ano. Já os testes da Provinha Brasil devem ser aplicados no primeiro e no segundo semestre do $2^{\circ}$ ano. Ou seja, pretendem avaliar o desempenho dos alunos provenientes do $1^{\circ}$ ano - Teste 1 e os que findam o $2^{\circ}$ ano - Teste 2 .

41 Como mais um estudo que decorre da interlocução com os autores das áreas de estudos que utilizamos, muitos deles colegas da universidade ou de outras instituições, aproveitamos para agradecer as parcerias, marcadas por proximidades, como também, por diferenças. Aproveitamos, nesse sentido para agradecer aos pareceristas anônimos pelas contribuições acrescidas a este artigo e, especialmente, à Rosa Maria Hessel Silveira, leitora escolhida por nós para sua finalização, que consideramos nossa grande referência acadêmica, e, sobretudo, uma grande amiga.

\section{Referências}

BARKER, Chris; GALASINSKI, Dariusz. Cultural Studies and Discourse Analysis. In: BARKER, Chris; GALASINSKI, Dariusz. A Dialogue on Language and Identity. London: Sage, 2001. P. 01-27.

BARROS, João de. Cartinha para aprender a ler. In: BUESCU, Maria Leonor Carvalhão. Gramática da Língua Portuguesa: cartinha, gramática, diálogo em louvor da nossa linguagem e diálogo da viciosa vergonha. Lisboa: Publicações da Faculdade de Letras da Universidade de Lisboa, 1971 (Reprodução fac-similada da primeira edição da Cartinha para aprender a ler de João de Barros, datada de 1539).

BRASIL. Ministério da Educação. Provinha Brasil: passo a passo: teste 2. Brasília: MEC/INEP, 2008a. 
BRASIL. Ministério da Educação. Provinha Brasil: caderno de teste do aluno: teste 1. Brasília: MEC/INEP, 2008b.

BRASIL. Ministério da Educação. Provinha Brasil: caderno de teste do aluno: teste 2. Brasília: MEC/INEP, 2008c.

BRASIL. Ministério da Educação. Provinha Brasil: guia de correção e interpretação de resultados. Teste 1. Brasília: MEC/INEP, 2008d.

BRASIL. Ministério da Educação. Guia de Livros Didáticos: PNLD 2010: letramento e alfabetização/língua portuguesa. Brasília: Ministério da Educação, Secretaria de Educação Básica, 2009a.

BRASIL. Ministério da Educação. Provinha Brasil: passo a passo: teste 2. Brasília: MEC/INEP, 2009b.

BRASIL. Ministério da Educação. Provinha Brasil: caderno do professor / aplicador II: guia de aplicação: teste 1. Brasília: MEC/INEP, 2009c.

BRASIL. Ministério da Educação. Provinha Brasil: caderno de teste do aluno: teste 2. Brasília: MEC/INEP, 2010.

BUESCU, Maria Leonor Carvalhão. Gramática da Língua Portuguesa: cartinha, gramática, diálogo em louvor da nossa linguagem e diálogo da viciosa vergonha. Lisboa: Publicações da Faculdade de Letras da Universidade de Lisboa, 1971.

CAGLIARI, Luiz Carlos. O que é Preciso Saber para Ler. In: MASSINI-CAGLIARI, Gladis; CAGLIARI, Luiz Carlos (Org.). Diante das Letras: a escrita na alfabetização. Campinas: Mercado de Letras, 1999. P. 131-159.

CARPANEDA, Isabella; BRAGANÇA, Angiolina. Porta Aberta: letramento e alfabetização linguística: $1^{\circ}$ ano. São Paulo: FTD, 2008.

CASTILHO, António Feliciano de. Guia Momentania para uso dos Professores do Método Portuguez. Porto: Typ. de J. A. de Freitas Junior, 1854a.

CASTILHO, António Feliciano de. Ajuste de Contas com os Adversários do Méthodo Portuguez. Coimbra: Imprensa da Universidade, 1854b.

CASTILHO, António Feliciano de. Quadros Alphabeticos de Illuminados para as Escolas de Leitura e Escripta pelo Methodo-Portuguez-Castilho. 44 estampas. Lisboa: Imprensa de Lucas Evangelista, 1854c.

CASTILHO, António Feliciano de. Método Castilho para o Ensino Rápido e Aprazível do Ler Impresso, Manuscrito, e Numeração e do Escrever. Obra tão própria para as escolas como para uso das famílias. 3 ed. Inteiramente refundida, aumentada, e ornada de um grande numero de vinhetas. Lisboa: Imprensa Nacional, 1853

CIRNE JUNIOR, F. A. do Amaral. A Arte da Leitura de João de Deus. In: FERREIRA, Alberto. Antologia de Textos Pedagógicos do Século XIX Português. v. II. Instituto Gulbekian de Ciência/Centro de Investigação Pedagógica, Lisboa, 1973. P. 307-327.

COSTA, Marisa V.; SILVEIRA, Rosa Hessel; SOMMER, Luis Henrique. Estudos Culturais, educação e pedagogia. Revista Brasileira de Educação, Rio de Janeiro, n. 23, maio/ago. 2003

COSTA, Marisa V. Novos olhares na pesquisa em educação. In: COSTA, Marisa V. (Org.). Caminhos Investigativos: novos olhares na pesquisa em educação. Rio de Janeiro: DP\&A, 2002. P. 13-22.

DEUS, João de. Cartilha Maternal ou Arte de Leitura por João de Deus. Publicada por Candido J. A. de Madureira, Abbade de Arconzello. Porto: Livraria Universal de Magalhães \& Moniz, 1876. (Cópia fac-similada da $1^{\mathrm{a}}$ edição) 
A Atualização dos Primeiros Métodos de Alfabetização...

ESCOLANO BENITO, Agustín. Tradición e innovaciones en los libros de iniciación a la lectura de la España de entre siglos. In: ESCOLANO BENITO, Agustín (Org.). Historia Ilustrada del Libro Escolar en España. Madrid: Fundación Germán Sánchez Ruipérez, 1997. P. 229-254.

FERrEIRO, Emilia; TEBEROSKY, Ana. Psicogênese da Língua Escrita. Porto Alegre: Artes Médicas, 1985.

GOMES, Joaquim Ferreira. A Educação Infantil em Portugal: achegas para a sua história. Coimbra: Almedina, 1977.

GROSSI, Esther Pillar. Didática do Nível Alfabético. Rio de Janeiro: Paz e Terra, 1990a.

GROSSI, Esther Pillar. Didática do Nível Pré-Silábico. Rio de Janeiro: Paz e Terra, 1990b.

GROSSI, Esther Pillar. Didática do Nível Silábico. Rio de Janeiro: Paz e Terra, 1990c.

GUIMARÃES, Eduardo. Os Estudos sobre Linguagem: uma história das ideias. Disponível em: <http://www.consciencia.br/reportagens/linguagem/lingl4. htm>. Acesso em: 14 ago. 2001.

HALL, Stuart (Org.). Representation: cultural representations and signyfing practices. London: Sage Publications, 1997.

JUANÉDA-ALBARÉDE, Christiane. Cent ans de Methods de Lecture. Montreal: Albin Michel Education, 1998.

LAGE, Bernardino da Fonseca. Metodologia Especial: a língua e a literatura portuguesa na educação primária. Lisboa/ Porto/ Coimbra: LVMEN, 1924.

MATTELART, Armand. Introdução aos Estudos Culturais. São Paulo: Parábola, 2004.

MELLO, Darlize Teixeira de. Provinha Brasil (ou provinha de leitura?): mais "uma avaliação sob medida" do processo de alfabetização e "letramento inicial?". 2012. 402 f. + Anexos. Tese (Doutorado em Educação) - Faculdade de Educação, Programa de Pós-Graduação em Educação, Universidade Federal do Rio Grande do Sul, Porto Alegre, 2012.

MORAIS, Artur Gomes de. Concepções e Metodologias de Alfabetização: por que é preciso ir além da discussão sobre velhos "métodos"?. 2006. Disponível em: <http://portal.mec.gov.br/seb/arquivos/pdf/Ensfund/alf_moarisconcpmetodalf.pdf $>$. Acesso em: 31 jul. 2013.

PICCOLI, Luciana. Prática Pedagógica nos Processos de Alfabetização e de Letramento: análises a partir dos campos da sociologia da linguagem. 2009. 207 f. + Anexos. Tese (Doutorado em Educação) - Programa de Pós-Graduação em Educação, Faculdade de Educação, Universidade Federal do Rio Grande do Sul, Porto Alegre, 2009.

SCHNEIDER, Marilda Pasqual; MOZZ, Gabriela Strauss. Para Onde Encaminham as Orientações Curriculares no Ciclo de Alfabetização? In: COLÓQUIO INTERNACIONAL DE EDUCAÇÃO E I SEMINÁRIO SOBRE INDICADORES DE QUALIDADE DO ENSINO FUNDAMENTAL, 3., 2011, Joaçaba. Anais eletrônicos... Joaçaba: UNOESC, 2011. 11f. Disponível em: <http://editora.unoesc.edu. $\mathrm{br} /$ index.php/coloquiointernacional/index/http/coloquiointernacional/issue/ view/65/showToc >. Acesso em: 29 abr. 2012.

SILVA, Thaise da. Os "Novos" Discursos sobre Alfabetização em Análise: os livros de $1^{\circ}$ ano do ensino fundamental de nove anos do Programa Nacional do Livro Didático (PNLD 2010). 2012. 282 f. Tese (Doutorado em Educação) - Pro-

856 Educação \& Realidade, Porto Alegre, v. 40, n. 3, p. 829-857, jul./set. 2015. 
grama de Pós-Graduação em Educação, Faculdade de Educação, Universidade Federal do Rio Grande do Sul, Porto Alegre, 2012.

SOARES, Magda. Dicionário Crítico da Educação: letramento/alfabetismo. Presença Pedagógica, Belo Horizonte, v. 2, n. 10, p. 83-89, jul./ago. 1996.

TRINDADE, Iole Maria Faviero. A Invenção de uma Nova Ordem para as Cartilhas: ser maternal, nacional e mestra: queres ler? Bragança Paulista: Ed. Universitária São Francisco, 2004. 488 p.

TRINDADE, Iole Maria Faviero. A Invenção de uma Nova Ordem para as Cartilhas: ser maternal, nacional e mestra: queres ler? 2001. $490 \mathrm{f}$.: il. Tese (Doutorado em Educação) -Programa de Pós-Graduação em Educação, Faculdade de Educação, Universidade Federal do Rio Grande do Sul, Porto Alegre, 2001.

VEIGA-NETO, Alfredo. Olhares... In: VORRABER, Marisa Costa (Org.). Caminhos Investigativos: novos olhares na pesquisa em educação. Porto Alegre: Mediação, 1996. P. 19-35.

Iole Maria Faviero Trindade é pedagoga, mestre e doutora pela Universidade Federal do Rio Grande do Sul, professora aposentada da área de Linguagem e Educação do Departamento de Ensino e Currículo (DEC) e pesquisadora do Núcleo de Estudos sobre Currículo, Cultura e Sociedade (NECCSO) da FACED/UFRGS, com estudos na área da alfabetização.

E-mail: ioletrin@terra.com.br

Darlize Teixeira de Mello é pedagoga, mestre e doutora pela Universidade Federal do Rio Grande do Sul, professora adjunta da Universidade Luterana do Brasil - Curso de Pedagogia/Canoas, e da Rede Municipal de Ensino de Porto Alegre e pesquisadora associada do Núcleo de Estudos sobre Currículo, Cultura e Sociedade (NECCSO) da FACED/UFRGS, com estudos na área da alfabetização.

E-mail: darlizemello@terra.com.br

Thaise da Silva é pedagoga, mestre e doutora pela Universidade Federal do Rio Grande do Sul, professora adjunta da área de Currículo e Alfabetização da FAED/UFGD e pesquisadora associada do Núcleo de Estudos sobre Currículo, Cultura e Sociedade (NECCSO) da FACED/UFRGS, com estudos na área da alfabetização.

E-mail: thaisesilva@ufgd.edu.br 